\title{
Effect of Working Capital Management on the Profitability of Listed Consumer Goods Companies in Nigeria
}

\author{
Ahmed Abubakar Abdullahi PhD \\ Department of Accounting and Finance, Adamawa State University Mubi, Adamawa State \\ Ibitomi Opeyemi \\ Department of Accountancy, Federal Polytechnic Mubi, Adamawa State
}

\begin{abstract}
The study examines the effect of working capital management on the profitability of consumer goods companies listed on the Nigerian Stock Exchange. Specifically, the study sought to determine the extent to which number of days account receivables, inventory, and number of day of account payable affects return on asset (ROA) of consumer goods companies on the NSE. The populations for the study consist of consumer goods companies listed on Nigerian Stock Exchange. The study covers a period of 5 years from 2014-2018. Data collected were analyzed using multiple regression analysis via the Statistical Package for Social Science (SPSS) version 20. The study reports a negative and insignificant influence of trade receivable collection period and trade payable payment period on ROA while inventory conversion period has a positive insignificant effect on ROA of consumer goods companies. Therefore, it is concluded that working capital management has insignificant effect on companies' profitability in consumer goods companies in Nigeria. The study recommends that companies should adopt a policy of prompt collection of debts, ensure adequate liquidity by ensuring current assets exceed current liabilities. Keywords: Working Capital, Profitability, Accounts Trade Receivable Collection Period, Trade Payable Payment Periods, Inventory Conversion Period
\end{abstract}

DOI: $10.7176 /$ RJFA/11-18-14

Publication date: September $30^{\text {th }} 2020$

\subsection{Introduction}

The primary goal of any financial manager is to maximize profit and without this, the going concern of any business operations would be threatened in the long run. Managers are therefore continuously adopting and adapting business strategies to improve profitability to an acceptable level. And of such strategies is the composition of assets and liabilities in the statement of financial position as well as quality of decisions made in this respect (Pandey, 2005). Working capital (current assets and current liabilities) constitutes a major component of total asset and total liabilities of manufacturing companies that must be properly managed and hence the effect on profitability cannot be underestimated. Working capital management is the ability to control effectively and efficiently the current assets and current liabilities in a manner that provides the company with maximum return on its assets and minimizes payments for its liabilities (Charitou, Elfani \& Lois 2010). Working capital management is significant to a company and this is usually explained by the relationship between working capital management and profitability (Oladipo \& Okafor 2013). They were of the opinion that working capital is important to the financial health of businesses organization of all sizes.

A large number of business failures in the past have been blamed on the failure of financial managers to carry out a proper plan and control of working capital of their respective companies. These reported inadequacies among financial managers are still in existence today in the likes of high bad debts, inventory cost etc., which adversely affect their operating performance (Ebide 2009). Also, the Nigerian economy is faced with several hindrance factors such as bad governance, corruption, lack of policy implementation and persistence competition which impede the speed of having a huge return on the resources employed and invested by manufacturing industries in Nigeria. The sustainability of a company heavily depends on the ability and efficient utilization of financial management function (Karaduman, 2011). As a result, proper planning and efficient capital management is required in order to manage the outcome pressure from highly competitiveness in the economy. Owolabi and Aleyomi (2010), working capital is a vital element in any organization setting that requires maximum attention, proper planning and management.

The decisions relating to working capital must not be taken for granted. It is important to manage it well, as it has generous effect on the financial performance and failure to manage it well may lead to collapse of business (Deloof, 2003). To this end, Samuel and Fidelis (2015) assert that if there is too little working capital, it results in inventories, finished goods and customer credit not being available in sufficient quantity. On the other hand, if there exits excessive levels of working capital, the company has unnecessary additional costs; cost of tying up fund plus cost of storage, ordering and handling cost of being overburdened with stock. This creates a sort of imbalance in the working capital components, making it difficult to manage. As a result therefore, the ultimate goal of working capital management is to ensure that companies are able to continue their operations with sufficient 
cash flow that will service their long term debt and satisfy both maturing short term debt obligations (debt) and unforeseen operational cost. Hence, organizations should try as much as possible to meet up with this objective to avoid be caught up in the trap of inefficient management of working capital components.

\subsection{Objectives of the Study}

In this paper, working capital management and profitability of listed consumer goods companies in Nigeria is empirically examined, with objectives of determining the extent to which working capital management affects profitability.

\subsection{Literature Review}

Working capital management has elicited considerable interests among scholars and researchers and generated several studies and viewpoints in different environments. The following sections explore some of these works.

\subsection{Profitability as an Objective of a Company}

Companies have numerous objectives but the prime one among them is shareholders' wealth maximization and to achieve this, companies needs to maximize its profit. Businesses cannot survive in the long run without profitability (Damilola 2007). Profit as the most appropriate measure of corporate performance, it is a tool for efficient resources allocation under competitive market conditions (Pandey, 2005). Conceptually, profitability refers to the ability of companies to generate profit on the amount invested. It is measured with income and expenses. Expenses are the costs of resources used up or consumed by the activities of the business. It is the level at which company's earnings is bigger than its cost (Paul \& Agbo, 2014). Profitability refers to the company's ability to generate profits as return on their money invested; profitability ratios reflect the competitive situation of the company in addition to the quality management. It is reflects the success or failure of the company (Robinson, Henry, Pirie \& Broihahn 2015). Profitability ratios include the following return on capital employed, return on shareholder capital, return on asset, return on equity, gross profit, operating profit and net operating profit (Owolabi \& Aleyomi 2010; Samuel \& Fidelis 2015; David, 2010; Francis 2015; Karaduman 2011). This paper adopts ROA as measure of profitability.

\subsection{Nature and Working Capital Strategies}

The primary objective of any company is profitability and for any company to maximize its profit, it must ensure a balance between current assets and current liabilities (working) capital) (Haris 2005). Working capital refers to the cash utilization by business firms in their daily operational activities. According to Adeniji (2008), it is capital available for conducting day-today operations of an organization represented by its current asset. In the same vein, it is an item that is needed for the day-to-day production of goods to be sold by a company (Akinlo 2011). Uremadu, Egbeide and Enyi (2014), described working capital as the item required for the day-to-day production of goods to be sold by a company. Working capital is the amount invested in current assets of the company. Generally, it is assumed that the ideal ratio of current asset to current liabilities is 2 to 1 . Working capital is one of the most important problems that company's manager may face. It plays an importance role for the company's' maintenance and growth. Working capital is the stock stored that has a conversion or resale value in order to gain profit. It consists of about $30 \%$ to $40 \%$ of a company's total investment (Nwachukwu, Odo \& Nwachukwu, 2016). The current asset component of working capital are asset which can be converted into cash within an accounting year and consist majorly of cash and cash equivalents, trade receivables, short term securities, bills receivables and inventories. Current liabilities components are those claims of outsiders which are expected to mature for payment within an accounting year and consist of trade payables or creditors, bills payable and outstanding expenses (Pandey 2005).

The return earned by a company depends to a large extent on the investment in working capital. Nevertheless too much investment in current asset can result in a company getting low return on investment while companies with few current assets may also face challenges in meeting its daily and smooth operations. According to Abdul and Mohammed (2007), they stated that the reason why managers spend more time on daily management of working capital is that current assets are short lived investments that are often being transformed into other types of asset. Working capital management is therefore a crucial area in financial management. It involves the decision of the amount and composition of current assets and the financing of those assets (Abdulrasheed, Khadijat, Sulu \& Olarewaju, 2011). To ensure a proper management of working capital, a company must consciously formulate polices or principles relating to each components of working capital (receivables payables and inventories cash and short-term investments) in order to minimize the possibility of illiquidity and inefficiency (Damilola, 2007; Chittenden, Poutziouris, \& Michaelas, 1998) as stated in Musa \& Adamu 2018).

A company can usually adopt one of the three types of working capital policies; namely aggressive, conservative and moderate polices (Damilola, 2007). An aggressive policy with regard to the level of investment in working capital means that a company chooses to operate with lower levels of inventory, trade receivables and 
cash for a given level of activity or sales (Chittenden et al., 1998). According to them an aggressive policy will increase profitability since less cash will be tied up in current assets, but it will also increase risk since the possibility of cash shortages or running out of inventory is increased.

The second strategy is the conservative and more flexible working capital strategy for a given level of turnover would be associated with maintaining a larger cash balance, perhaps even investing in short-term securities, offering more generous credit terms to customers and holding higher levels of inventory (Chittenden et al., 1998). Such a policy will give rise to a lower risk of financial problems or inventory problems, but at the expense of reducing profitability.

The third strategy a company could adopt is the moderate working capital policy. A moderate policy would tread a middle path between the aggressive and conservative approaches. It should be noted that the working capital policies of a company can be characterized as aggressive, moderate or conservative only by comparing them with the working capital policies of similar companies (Chittenden et al., 1998). There are no absolute benchmarks of what may be regarded as aggressive or otherwise, but these characterizations are useful for analyzing the ways in which individual companies approach the operational problem of working capital management

\subsection{Working Capital Management and Profitability}

The review shall be based on previous studies related to the theme of the study which is found to be most relevant and related. Examination of various studies on the effect of working capital management present different opinions. While some noted a positive effect of WCM on profitability, some results indicated a negative effect of the independent variable on the dependent variable. Nevertheless, some results gave a mixed result of both positive and negative effect of WCM on profitability.

In Nigeria, Samuel, Abolade and Adeyemi (2019) studied the effect of working capital management on the profitability of listed manufacturing firms in Nigeria. The study was based on secondary data and the study period was 2006-2015. 30 firms listed on the Nigerian Stock Exchange were selected for the study. Panel data was applied as research methodology. The result show account payment period is statistically significant and has negative effect on profitability and it also indicates that account collection periods have negative effect on profitability. Following similar result is the study by Musa and Adamu (2018) on the effect of working capital management on profitability of listed bottling companies in Nigeria. A total of 7 bottling companies were considered for the study for a period of 2001-2014. Multiple regression analysis was adopted for the study and the study reveals that inventory turnover days has a positive and strong impact on profitability. The study also reveals that account receivable days have negative but significant effect on profitability while account payable days has positive but insignificant impact of profitability. Paul and Agbo (2014) in their study examined the impact of working capital management on the profitability of Nigerian cement industries for a period of 2002-2009 with a target population of 5 cement companies. Multiple regression analysis was analysis was adopted and the result indicates an insignificant negative relationship between the profitability (measured by ROA) and the number of days accounts receivables are outstanding. The study also found a significant negative relationship between the profitability of these cements companies and the number of day inventory are held. The study finally revealed a significant positive relationship between the profitability and the cash conversion cycle.

Richard, Dadson and Peter (2013) examined working capital management: evidence from Ghanaian listed manufacturing firms. Secondary data were used for their study which covered 13 listed manufacturing firms in Ghana for a period of 2005-2009 using panel data methodology. Their study revealed that account receivable days has negative effect on profitability while account payable days has negative but insignificant effect on profitability. Also in South Africa, Jason (2017) conducted a study on the effect of working capital management on profitability with his study centres on listed manufacturing firms in South Africa with a total of 69 manufacturing firms. The study covers a period of 2007-2016 and panel data was used in analyzing the data. The findings revealed that the average collection period and the average payment period are negative and statistically significant for profitability, implying that firms which efficiently manage their accounts receivable and those that pay their creditors on time perform better than those that do not. Additionally, a positive statistically significant relationship between the number of days in inventory and profitability was supported suggesting that firms which stock-up and maintain their inventory levels suffer less from stock-outs and avoid challenges of securing financing when needed. Also in Kenya, Daniel and Ambrose (2013) examined working capital management and profitability of listed manufacturing and construction firms listed on the Kenya Securities Exchange for a period of 2003-2012. Ordinary least square regression model were used in analyzing the data and the result revealed that number of days account receivable and number of days account payable have negative effect on profitability while number of days inventory turnover has positive effect on profitability.

Arunkumar and Radharamanan (2012) examined the effect of working capital management on profitability of Indian manufacturing firms. The study period was of 2005-06 to 2009-10 i.e. for 5 years and methodology used on this study was correlation and regression analysis. The results of research shows that in correlation analysis 
profitability has negative relationship between profitability and debtor day, inventory day and creditor day. And a result of regression analysis shows that there is positive relationship between number days of inventory and number of days of account payables. Also, Asefi, Bandarian and Ghatebi (2013) examined the effect of working capital management on the profitability of listed companies in Tehran Stock Exchange. Research data was analyzed using population of 116 listed companies in Tehran Stock Exchange for the period of 2006-2011 by applying combination method of all data (pooled data) and ordinary least square regression (OLS). The research result indicates that, there was a significant inverse relationship between collection period, inventory period, accounts payables and profitability of the firms. Ahsen, Faisal and Muhammad (2011) investigated the relationship between profitability and working capital management. The study sampled 60 textile companies listed at Karachi Stock Exchange (KSE) for the period of 2001-2006 and the firm observation was 360. Data collected was analyzed Pearson correlation, Model Summary and ANOVA. The result of the research showed that there is statistical negative significance between profitability, measured through Return on Asset and cash conversion cycle and its components (Number of days Account receivables, Number of days Accounts payables and Number of days Inventory).

\subsection{The Methodology of the Study}

The research design adopted for this study was correlation research design approach. The target population consists of consumer goods companies listed on the Nigerian Stock Exchange. This involves a total of 24 companies out of which 13 companies were selected. Others were left out due to non-availability or incomplete data during the period under study. The data used in this work were extracted from the annual reports and accounts of sampled companies covering the period of 2014-2018 and transformed into the specific attributes of variables for the number of years the research cover. Microsoft Excel software was used to transform the variables into a format suitable for analysis, after which the Statistical Package for Social Science (SPSS) was used to analyze the data.

\subsection{Variable Operationalization}

This study establishes the relationship between working capital management and profitability and profitability is proxied by return of assets (ROA) is our dependent variables while working capital management measured by working capital components TRCP (Trade Receivables Collection Period), ICP (Inventory Conversion Period), TPPP (Trade Payable Payment Period) is our independent variable. ROA is a measure of the overall effectiveness of the company in generating profit with available assets.

The independent variables are computed as follows:

TRCP $=$ Trade receivable/Sale*365 days

ICP $=$ Inventory $/$ Cost of sales $* 365$ days

TPPP $=$ Trade payable/cost of sales $* 365$ days

\subsection{Model Specification}

The analysis was guided by the following linear models $\mathrm{ROA}=\mathrm{f}(\mathrm{TRCP}, \mathrm{ICP}, \mathrm{TPPP}, \mathrm{COSIZE}$.)

Assuming a linear relationship between the variables, the specification of the regression equation for the main model 1 above could be written explicitly states as:

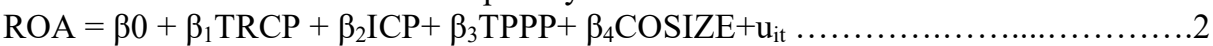

Where, ROA is return on assets (our measure of profitability), TRCP is the trade receivable collection period, ICP is the inventory conversion period, TPPP is the trade payables payment period. COSIZE connotes natural logarithm of total assets; it is included in the model as a control variable to measure company size. $\beta_{0}$ is the intercept of the regression and $\beta_{1}, \beta_{2}$ and $\beta_{3}$ are the coefficients of the regression, while $\mathrm{u}_{\mathrm{it}}$ is the error term capturing other explanatory variables not explicitly included in the model.

\subsection{Data Presentation, Analysis and Hypothesis Testing}

The data for this study representing the independent variables TRCP, ICP, TPPP and the control variables COSIZE were collected from the sampled companies for the period of 2014-2018. The tables of the data used are included in the appendix to this study.

\subsection{Data Analysis: Multiple Regression Analysis}

Regression analysis is used to find the effect of independent variables on dependent variables. In this study working capital management is taken as independent variable and financial performance proxied by return on asset is considered as dependent variables. The analysis was however guided by the specific model, which is recalled below:

$\mathrm{ROA}=\beta 0+\beta_{1} \mathrm{TRCP}+\beta_{2} \mathrm{ICP}+\beta_{3} \mathrm{TPPP}+\beta_{4} \mathrm{COSIZE}+\mathrm{u}_{\mathrm{it}}$

The summary of the summary of the regression results are presented in tables 1,2 and 3 ; 
Table 1: Model Summary

\begin{tabular}{|l|r|r|r|r|}
\hline Model & R & R Square & Adjusted R Square & Std. Error of the Estimate \\
\hline 1 & $.238^{\mathrm{a}}$ & .056 & -.006 & 17.1267640 \\
\hline
\end{tabular}

a. Predictors: (Constant), COSIZE, ICP, TRCP, TRPP

Table 2: ANOVA ${ }^{\mathrm{a}}$

\begin{tabular}{|c|c|c|c|c|c|c|}
\hline \multicolumn{2}{|c|}{ Model } & Sum of Squares & Df & Mean Square & $\mathrm{F}$ & Sig. \\
\hline \multirow{3}{*}{1} & Regression & 1053.676 & 4 & 263.419 & \multirow[t]{3}{*}{.898} & \multirow[t]{3}{*}{$.471^{\mathrm{b}}$} \\
\hline & Residual & 17599.563 & 60 & 293.326 & & \\
\hline & Total & 18653.239 & 64 & & & \\
\hline
\end{tabular}

a. Dependent Variable: ROA

b. Predictors: (Constant), COSIZE, ICP, TRCP, TRPP

Table 3: Coefficients ${ }^{\mathrm{a}}$

\begin{tabular}{|c|c|c|c|c|c|c|}
\hline \multirow[t]{2}{*}{ Mod } & & \multicolumn{2}{|c|}{ Unstandardized Coefficients } & \multirow{2}{*}{$\begin{array}{c}\text { Standardized } \\
\text { Coefficients } \\
\text { Beta }\end{array}$} & \multirow[t]{2}{*}{$\mathrm{t}$} & \multirow[t]{2}{*}{ Sig. } \\
\hline & & $\mathrm{B}$ & Std. Error & & & \\
\hline \multirow{5}{*}{1} & (Constant) & -3.042 & 32.645 & & -.093 & .926 \\
\hline & $\mathrm{TRCP}$ & -.018 & .033 & -.067 & -.532 & .597 \\
\hline & $\mathrm{ICP}$ & .023 & .050 & .075 & .473 & .638 \\
\hline & TRPP & -.026 & .016 & -.252 & -1.593 & .116 \\
\hline & COSIZE & 1.300 & 1.812 & .091 & .717 & .476 \\
\hline
\end{tabular}

a. Dependent Variable: ROA

From the result presented above, the standard coefficient are $-0.067,0.075,-0.252$ and 0.91 for TRCP, ICP, TRPP and COSIZE respectively, their P-value stands at 0.926, 0.597, 0.638, 0.116 and 0.476 ( $\mathrm{p}>0.05$ ) which are not significant. The negative sign in TRCP and TPPP indicates that a decrease in debt collection period will lead to an increase in profitability and verse versa though they are statistically not significant. This suggests that they are good in explaining the financial success of consumer goods companies but not a critical factor when making a decision on improving profitability. The result is consistent with David and Ambrose (2013); and Richard, Dadson and Peter (2013); and Asefin, Badarian and Ghatebi (2013) but contradict the finding of Musa and Adamu (2018). Also inventory turnover days shows a beta value of 0.075 and a $(p>0.05)$ which is positive but has insignificant effect of companies profitability. The result is consistent with the findings of Arunkumar and Radharamanan (2012); and Jason (2017). This result contradicts the finding of Paul and Agbo (2014). The result of company size also show positive but insignificant effect on companies profitability

\subsection{Hypothesis Testing}

This study was anchored on one principal hypothesis that 'working capital management, measured by its components (TRCP, ICP, and TPPP) has no significant effect on the profitability of listed consumer goods companies in Nigeria. The regression results indicate that only one of the components of working capital management (TPPP) has a significant effect on ROA. However the combined effect of the independent variables of $8.1 \%$ on the dependent variable is respected.

Besides, the ANOVA table shows an F-value of 0.898 and p-value is 0.471 which is greater than 0.05 means that working capital management as a whole has no significant effect on ROA of listed consumer goods companies in Nigeria. We hereby accept the null hypothesis.

\subsection{Conclusion and Recommendations \\ 6.1 Conclusion}

This paper examines the effect of working capital management on the profitability of listed consumer's goods companies in Nigeria. This research work covered 13 listed consumer goods companies for a period of 2014-2018. For measuring working capital management, trade collection receivable period, inventory conversion period and trade payable payment period were taken as independent variables. Company profitability is measured by return on assets. Working capital forms an essential part of total assets and liabilities of many manufacturing companies in Nigeria. Therefore its management will have a significant effect on profitability. Regression analysis was used to find out the effect of working capital management on company's profitability by using secondary data. The paper discovered that all the components of WCM affects profitability at varying levels. Also the paper revealed that the combined effect of the components of WCM has a relative significant predictable power on profitability. 


\subsection{Recommendations}

Based on the revelation from this study we make the following recommendations

i. The result of this study suggests that account receivable days are an important factor that affects profitability of Consumer Goods Company. The study therefore, recommends that managers of consumer goods Company in Nigeria should continuously monitor their account receivables days with a view to reducing the number of day's cash are tied up with customers in order to make it available for running the business.

ii. To ensure adequate liquidity, companies should maintained a standard of 2:1 of current asset to current liabilities as this will provide adequate cash to meet current obligations.

\section{REFERENCES}

Abdul, \& Mohammed. (2007). Working Capital Management and Profitabilty - Cases of Parkistani Firm. International Review of Business Research Paper, 3(1) 279 - 300.

Abdulrasheed, A., Khadijat, A. Y., Sulu, I., \& Olarewaju, A. A. (2011). Inventory Management in Small Business Finance Empirical Evidence from Kwara State. British Journal of Economics Finance and Management Science, 2(1) 49-57.

Adeniji, A. A. (2008). Insight to Management Accounting. Lagos: El-Toda Venture Ltd.

Ahsen, S., Faisal, M. H., \& Muhammad, N. H. (2011). Working Capital Management and Profitability: Evidence from Pakistan Firms. Interdisciplinary Journal of Management Economics and Social Sciences , 3(8), 10921105.

Akinlo, O. O. (2011). The Effect of Working on Profitability Method of Moments (GMM). Asian Journal of Business and Management Sciences, 1(2) 130-135.

Arunkumar, O. N., \& Radharamanan, T. (2012). Analysis of the Effects of Working Capital Management on Corporate Responsibility of Indian Manufacturing Firms. International Journal of Business Insight and Transformation, 5(1), 71-76.

Asefi, N. D., Bandarian, A., \& Ghatebi, M. (2013). A Study on the Effect of Working Capital Management on the Profitability of Listed Companies in Tehran Stock Exchange. Academic Journal of Accounting and Economics Researches, 2(4), 1-10.

Charitou, Elfani, \& Lois. (2010). The Effect of Working Capital Management on Firms Profitability: Empirical evidence from emerging market . Journal of Bussiness and Economic research, 8(12) 63-68.

Chittenden, F., Poutziouris, P., \& Michaelas, N. (1998). Financial Management and Working Capital Practices in UK SMEs. Manchester: Manchester Business School.

Damilola, D. A. (2007) Corporate Finance: Issues, Investigations, Innovations \& Application (2nd Ed) Lagos, High Rise Publications

Daniel, M. M., \& Ambrose, J. (2013). Working Capital Management and Firm Profitability: Evidence from Manufacturing and Construction Firms Listed on Nairobi Security Exchange, Kenya. International Journal of Auditing and Taxation, 1(1),1-14.

David, M. M. (2010). The Influence of Working Capital Management Components on Corporate Profitability. A survey of Kenya listed firms. Research Journal of Business Management, 1-11 4(1).

Deloof, M. (2003). Does Working Capital Management Affects Profitability of Belgian Firm? Journal of Business Finance and Accounting, 30(3), 573-587

Ebide, B. (2009). Working capital Management and Profitabilty of Listed Companies in Nigeria. Nigeria Research Journal of Accountancy, 1(1) 44-45.

Francis, O. A. (2015). Relatioship between Working Capital Mangement and Profitabilty of Cement Companies in Kenya. Research Journal of Fiance and Accounting , 6(7) 154-182.

Harris, A. (2005). Working Capital Management: Difficult but Rewarding. Financial executive , 21(4) 52-53.

Jason, K. (2017). Effect of Working Capital Management on Profitability: A Case of listed Firms in South Africa. Investment Management and Finance Journal, 14(2), 336-346.

Karaduman, H. A. (2011). The Relationship between Working Capital Management and Profitabilit; Evidence from emerging Markest. International Research Journal of Finance and Economic, 61-67.

Musa, I., \& Adamu Y. (2018). Effect of Working Capital Management on Profitability of Quoted Bottling Companies in Nigeria. International Journal of Economics, Commerce and Management, 6(8), 402-417.

Nwachukwu, J. O., Odo, S. I., \& Nwachukwu, N. C. (2016). Effect of Working Capital Management on Profitabilty of Flour Mills of Nigeria PLC . Reserach Journal of Finance and Accoutning, 7(14) 188-198.

Oladipo, A. O., \& Okafor, C. A. (2013). Relative Contribution of Working Capital Management to Coporate Profitability and Dividend Payout Ratio: Evidence from Nigeria. InternatiJournal of Business and Finance, 3(2) 11-20.

Owolabi, S. A., \& Aleyomi, S. A. (2010). The Study of Working Capital Management as a Financial Strategic. A Case Study of Nestle Nigeria Plc. Asian journal of Business and Management, 2(4)120-126. 
Pandey, I. M. (2005). Financial Management. $\left(9^{\text {th }}\right.$ Ed)New Delhi: Vikas publishing House Pvt Limited.

Paul, A. A., \& Agbo, A. (2014). Impact of Working Capital on the Profitability of Nigerian Cement Industires. European Journal of Accounting, Auditing and Finance, 2(7), 17-30.

Richard, K. A., Dadson, A. V., \& Peter, L. A. (2013). Working Capital Management and Profitabilty: Evidence from Ghanaian Manufacturing Firms. Journal of Economics and International Finance, 5(9), 373-379.

Robinson, T., Henry, E., Pirie, W., \& Broihahn, M. (2015). Internal Financial Statement Analysis. New Jersey: John Wiley and Sons Inc.

Samuel, A. O., Abolade, F. A., \& Adeyemi, S. O. (2019). Effect of Working Capital Management on Profitability. A case of listed Manufacturing Firms in Nigeria. International Journal of Research and Innovation, 3(11), 230-238.

Samuel, M. T., \& Fidelis, A. A. (2015). Effect of Working Capital Management on Firms Profitabilty in Selected Nigeria Quoted Companies . International Journal of Economies, Commerce and Management , 4(10) $414-$ 438.

Uremadu, S. O., Egbide, B. C., \& Enyi, P. E. (2014). Working Capital Management, Liquidity among Quoted Firms in Nigeria, Evidence from the Productive Sector. Journal of Academic Research in Accounting, Finance and Management Science, 2(1) 80-89.

Appendix

Relevant financial ratios computed from the annual reports of (Cadbury Nig. Plc.)

\begin{tabular}{|l|l|l|l|l|l|}
\hline Ratios & 2018 & 2017 & 2016 & 2015 & 2014 \\
\hline TRCP & 38.25 days & 53.96 days & 55.91 days & 67.77 days & 72.81 days \\
\hline INVENTORY T & 71.41 days & 88.99 days & 79.26 days & 37.41 days & 39.46 days \\
\hline TRPP & 130.50 days & 126.116 days & 198.40 days & 214.51 days & 193.63 days \\
\hline ROA & $6.59 \%$ & $3.16 \%$ & $-1.92 \%$ & $5.48 \%$ & $8.28 \%$ \\
\hline CO.SIZE & $17.13 \%$ & $17.16 \%$ & $17.16 \%$ & $17.16 \%$ & $17.17 \%$ \\
\hline
\end{tabular}

Relevant financial ratios computed from the annual reports of (Nestle Nig. Plc.)

\begin{tabular}{|l|l|l|l|l|l|}
\hline Ratios & 2018 & 2017 & 2016 & 2015 & 2014 \\
\hline TRCP & 57.81 days & 46.98 days & 48.22 days & 58.98 days & 56.87 days \\
\hline INVENTORY T & 55.40 days & 60.91 days & 70.67 days & 47.03 days & 48.71 days \\
\hline TRPP & 144.66 days & 116.34 days & 219.62 days & 159.44 days & 118.51 days \\
\hline ROA & $36.78 \%$ & $42.04 \%$ & $25.01 \%$ & $28.68 \%$ & $28.05 \%$ \\
\hline CO.SIZE & $18.95 \%$ & $18.81 \%$ & $18.95 \%$ & $18.60 \%$ & $18.50 \%$ \\
\hline
\end{tabular}

Relevant financial ratios computed from the annual reports of (Nasco Allied Industry)

\begin{tabular}{|l|l|l|l|l|l|}
\hline Ratios & 2018 & 2017 & 2016 & 2015 & 2014 \\
\hline TRCP & 125.89 days & 75.57 days & 203.11 days & 109.48 days & 104.36 days \\
\hline INVENTORY T & 88.69 days & 64.51 days & 66.97 days & 59.71 days & $\underline{7.22 \text { days }}$ \\
\hline TRPP & 279.31 days & 287.44 days & 420.41 days & 229.10 days & 224.29 days \\
\hline ROA & $2.13 \%$ & $26.50 \%$ & $15.75 \%$ & $18.68 \%$ & $22.54 \%$ \\
\hline CO.SIZE & $17.23 \%$ & $17.22 \%$ & $15.75 \%$ & $16.61 \%$ & $16.35 \%$ \\
\hline
\end{tabular}

Relevant financial ratios computed from the annual reports of (Golden Guinness Breweries)

\begin{tabular}{|l|l|l|l|l|l|}
\hline Ratios & 2018 & 2017 & 2016 & 2015 & 2014 \\
\hline TRCP & 60.99 days & 66.57 days & 95.17 days & 47.56 Days & 64.23 days \\
\hline INVENTORY T & 73.63 days & 108.62 days & 79.00 days & 61.74 days & 30.03 days \\
\hline TRPP & 120.61 days & 202.49 days & 227.69 days & 180.81 days & 193.78 days \\
\hline ROA & $10.17 \%$ & $8.52 \%$ & $4.09 \%$ & $13.39 \%$ & $12.43 \%$ \\
\hline CO.SIZE & $18.85 \%$ & $18.80 \%$ & $18.74 \%$ & $18.61 \%$ & $18.71 \%$ \\
\hline
\end{tabular}

Relevant financial ratios computed from the annual reports of (International Breweries Plc.)

\begin{tabular}{|l|l|l|l|l|l|}
\hline Ratios & 2018 & 2017 & 2016 & 2015 & 2014 \\
\hline TRCP & 85.74 days & 155.58 days & 62.72 days & 64.97 days & 58.12 days \\
\hline INVENTORY T & 141.13 days & 251.92 days & 84.54 days & 88.21 days & 85.12 days \\
\hline TRPP & 268.98 days & 1177.59 days & 191.01 days & 141.16 days & 201.58 days \\
\hline ROA & $7.76 \%$ & $3.32 \%$ & $16.07 \%$ & $15.37 \%$ & $20.73 \%$ \\
\hline CO.SIZE & $19.55 \%$ & $19.26 \%$ & $17.32 \%$ & $17.22 \%$ & $17.01 \%$ \\
\hline
\end{tabular}


Relevant financial ratios computed from the annual reports of (Nigeria breweries Plc.)

\begin{tabular}{|l|l|l|l|l|l|}
\hline Ratios & 2018 & 2017 & 2016 & 2015 & 2014 \\
\hline TRCP & 39.55 days & 45.26 days & 15.94 days & 10.26 days & 15.94 days \\
\hline INVENTORY T & 60.08 days & 77.58 days & 63.99 days & 59.25 days & 79.79 days \\
\hline TRPP & 211.51 days & 233.57 days & 180.30 days & 219.94 days & 233.73 days \\
\hline ROA & $9.60 \%$ & $14.93 \%$ & $14.50 \%$ & $17.60 \%$ & $19.71 \%$ \\
\hline CO.SIZE & $19.78 \%$ & $19.77 \%$ & $19.72 \%$ & $19.69 \%$ & $16.67 \%$ \\
\hline
\end{tabular}

Relevant financial ratios computed from the annual reports of (Presco)

\begin{tabular}{|l|l|l|l|l|l|}
\hline Ratios & 2018 & 2017 & 2016 & 2015 & 2014 \\
\hline TRCP & 86.57 days & 58.87 days & 25.45 days & 97.04 days & 70.65 days \\
\hline INVENTORY T & 353.67 days & 289.03 days & 128.97 days & 105.83 days & 155.60 days \\
\hline TRPP & 616.93 days & 456.34 days & 140.85 days & 321.31 days & 387.54 days \\
\hline ROA & $10.77 \%$ & $16.99 \%$ & $38.37 \%$ & $8.88 \%$ & $16.59 \%$ \\
\hline CO.SIZE & $17.88 \%$ & $17.64 \%$ & $18.24 \%$ & $17.83 \%$ & $17.72 \%$ \\
\hline
\end{tabular}

Relevant financial ratios computed from the annual reports of (Unilever Nig. Plc.)

\begin{tabular}{|l|l|l|l|l|l|}
\hline Ratios & 2018 & 2017 & 2016 & 2015 & 2014 \\
\hline TRCP & 118.61 days & 118.34 days & 99.10 days & 62.51 days & 55.94 days \\
\hline INVENTORY T & 78.61 days & 72.64 days & 72.87 days & 59.05 days & 90.41 days \\
\hline TRPP & 108.53 days & 143.14 days & 169.88 days & 138.93 days & 98.93 days \\
\hline ROA & $12.63 \%$ & $10.04 \%$ & $9.43 \%$ & $9.85 \%$ & $10.46 \%$ \\
\hline CO.SIZE & $18.74 \%$ & $18.61 \%$ & $18.09 \%$ & $17.73 \%$ & $17.64 \%$ \\
\hline
\end{tabular}

Relevant financial ratios computed from the annual reports of (champion Breweries)

\begin{tabular}{|l|l|l|l|l|l|}
\hline Ratios & 2018 & 2017 & 2016 & 2015 & 2014 \\
\hline TRCP & 8.35 days & 95.37 days & 28.82 days & 66.40 days & 63.82 days \\
\hline INVENTORY T & 75.53 days & 63.81 days & 69.19 days & 51.08 days & 48.67 ays \\
\hline TRPP & 183.87 days & 119.69 days & 167.12 days & 246.62 ays & 330.99 ays \\
\hline ROA & $-2.44 \%$ & $5.98 \%$ & $6.40 \%$ & $2.03 \%$ & $-24.95 \%$ \\
\hline CO.SIZE & $16.16 \%$ & $16.13 \%$ & $16.11 \%$ & $16.15 \%$ & $16.08 \%$ \\
\hline
\end{tabular}

Relevant financial ratios computed from the annual reports of (Dangote flour Mill)

\begin{tabular}{|l|l|l|l|l|l|}
\hline Ratios & 2018 & 2017 & 2016 & 2015 & 2014 \\
\hline TRCP & 32.78 days & 21.01 days & 24.64 days & 32.67 days & 60.65 ays \\
\hline INVENTORY T & 99.95 days & 104.14 days & 54.016 days & 46.15 days & 50.45 days \\
\hline TRPP & 55.99 days & 59.50 days & 72.53 days & 69.98 days & 67.16 days \\
\hline ROA & $3.78 \%$ & $16.94 \%$ & $21.47 \%$ & $38.10 \%$ & $16.94 \%$ \\
\hline CO.SIZE & $18.61 \%$ & $18.67 \%$ & $18.15 \%$ & $17.65 \%$ & $17.79 \%$ \\
\hline
\end{tabular}

Relevant financial ratios computed from the annual reports of (Dangote Sugar Refinery Plc.)

\begin{tabular}{|l|l|l|l|l|l|}
\hline Ratios & 2018 & 2017 & 2016 & 2015 & 2014 \\
\hline TRCP & 226.71 days & 130.61 days & 119.10 days & 178.81 ays & 163.23 ays \\
\hline INVENTORY T & 112.27 days & 117.40 days & 66.31 days & 70.85 days & 141.13 days \\
\hline TRPP & 179.47 days & 180.30 days & 219.94 days & 115.90 days & 119.08 days \\
\hline ROA & $28.01 \%$ & $11.92 \%$ & $18.47 \%$ & $18.40 \%$ & $19.55 \%$ \\
\hline CO.SIZE & $19.69 \%$ & $18.98 \%$ & $18.47 \%$ & $18.40 \%$ & $19.55 \%$ \\
\hline
\end{tabular}

Relevant financial ratios computed from the annual reports of (Flour Mill Nig. Plc.)

\begin{tabular}{|l|l|l|l|l|l|}
\hline Ratios & 2018 & 2017 & 2016 & 2015 & 2014 \\
\hline TRCP & 66.93 days & 71.65 days & 108.26 days & 113.11 days & 80.63 days \\
\hline INVENTORY T & 129.59 days & 121.73 days & 144.59 days & 101.29 days & 127.70 days \\
\hline TRPP & 63.05 days & 78.93 days & 86.03 days & 121.39 days & 116.20 days \\
\hline ROA & $45.54 \%$ & $14.09 \%$ & $11.25 \%$ & $10.70 \%$ & $14.88 \%$ \\
\hline CO.SIZE & $15.19 \%$ & $16.16 \%$ & $16.26 \%$ & $16.28 \%$ & $16.21 \%$ \\
\hline
\end{tabular}

Relevant financial ratios computed from the annual reports of (Vita Form Plc.)

\begin{tabular}{|l|l|l|l|l|l|}
\hline Ratios & 2018 & 2017 & 2016 & 2015 & 2014 \\
\hline TRCP & 88.65 days & 78.62 days & 97.93 days & 116.88 days & 871.49 days \\
\hline INVENTORY T & 77.52 days & 71.44 days & 60.80 days & 85.39 days & 76.51 days \\
\hline TRPP & 43.35 days & 62.68 days & 47.40 days & 43.57 days & 44.74 days \\
\hline ROA & $12.11 \%$ & $9.64 \%$ & $7.82 \%$ & $4.52 \%$ & $9.91 \%$ \\
\hline CO.SIZE & $19.69 \%$ & $19.66 \%$ & $19.29 \%$ & $19.26 \%$ & $19.21 \%$ \\
\hline
\end{tabular}

